УДК 342:351.86

DOI https://doi.org/10.51989/NUL.2021.4.11

\title{
ПЕРЕДУМОВИ ВИНИКНЕННЯ БЕЗПЕКОВОГО ДИСКУРСУ В ІСТОРІї ПОЛІтИКО-ПРАВОВОї ДУМКИ
}

\section{Загуменна Юлія Олександрівна,}

кандидат юридичних наук, доцент, професор кафедри теорії та історії держави і права

Харківського національного університету внутрішніх справ

У статті досліджуються передумови виникнення безпекового дискурсу в історії політикоправової думки. Феномен національної безпеки розглядається в політичному й правовому дискурсі.

Наголошується, що проблема формування безпекового дискурсу в історії політико-правової думки тривалий час досліджується різними науками: соціологією, релігієзнавством, безпекознавством (сек'юрітологією), етнографією, історією, історією держави й права, історією політичних і правових учень. Узагальнюючи, автор виділяє кілька пануючих парадигм у науці, які склалися в осмисленні порушеної проблематики, а саме: міфологічна (проблема безпеки в давньому світі постала як наслідок міфологізації природних і соціальних небезпек, їх міфолого-символічної інтерпретації у свідомості людини); філософська (поява безпекового дискурсу пояснюється ії виокремленням із загальнофілософського знання, його витоки й розвиток «синхронні» етапам розвитку філософії); антропологічна (формування вчення про безпеку людини й суспільства виводиться з природи людини, їі світу, потреб та інтересів); психологічна (безпекові питання оформлюються в окремий напрям мислення під впливом психологічної структури особистості, безпека людини має психологічну природу, вкорінена у свідомості людини); соціологічна (безпековий дискурс виводиться зі сфери соціального буття, соціального світу людини, наголошується на його соціальній зумовленості й структурованості); історична (безпековий дискурс має історичну зумовленість, їі витоки вбачаються в найдавнішому періоді історії людства, наголошується на цивілізаційній універсальності безпекового дискурсу); теологічна (пошуки шляхів забезпечення безпеки мають витоки в релігійності людини й невідворотно приводять ї̈ до Бога як найвищого гаранта безпеки й благодаті як у земному, так і в потойбічному світі). Установлено, що означені наукові парадигми так чи інакше перетинаються в дослідженні безпекового дискурсу й пошуках його витоків, меншою мірою конкурують, аніж раніше, взаємозбагачуються.

Зроблено висновок, що передумови виникнення безпекового дискурсу в історії політико-правової думки слід розглядати як сукупність соціальних і гносеологічних умов, що уможливили появу (виникнення) першопочаткових раціональних уявлень про співвідношення безпеки й небезпеки в житті людини, їх походження, засоби забезпечення безпеки й суб'єктів, здатних ї̈ забезпечити, задля подальшого розвитку цих уявлень у розвиткові політико-правових учень (доктрин) наступних історичних періодів. Формування такого дискурсу в розрізі соціальних передумов слід інтерпретувати як закономірний результат ускладнення соціального життя, його відокремлення від природного й надприродного світів, спроб осмислити безпеку як реальний і бажаний із боку загальносоціального інтересу стан захищеності людини від внутрішніх і зовнішніх загроз. Такими передумовами можна вважати виникнення людського суспільства з його поступовою соціальною диференціацією та структуруванням суб'єктів та об'єктів безпеки. Гносеологічними передумовами безпекового дискурсу стали перехід від предметно-конкретного до абстрактного мислення, формування перших абстрактних логічних «пракатегорій», які узагальнювали життєвий досвід людини щодо сфери бажаного, належного й безпечного, осмислення проблеми безпеки як універсальної для природного, соціального й надприродного (потойбічного) світів у структурі міфологічного мислення.

Ключові слова: безпека, первісне суспільство, свідомість, безпековий дискурс, соціальні передумови, гносеологічні передумови. 


\section{Zahumenna Yuliia. The preconditions for the emergence of security discourse within the history of political and legal thought}

The author of the article studies the preconditions for the emergence of security discourse within the history of political and legal thought. The phenomenon of national security is studied within political and legal discourse.

It is noted that the problem for forming security discourse within the history of political and legal thought has been studied by various sciences for a lon period of time - sociology, religious studies, securitology, ethnography, history, history of state and law, history of political and legal doctrines. Summing up, the author distinguishes several dominant paradigms in the science, which have been developed while understanding the mentioned problem, namely: mythological (the problem of security in the ancient world arose as a consequence of mythologizing natural and social dangers, their mythological and symbolic interpretation in human consciousness); philosophical (the emergence of security discourse is explained by its separation from general philosophical knowledge, its origins and development are "synchronous" to the stages of philosophy development); anthropological (formation of the doctrine on security of a man and society is derived from human nature, his world, needs and interests); psychological (security issues are modeled in a separate direction of thinking under the influence of the psychological structure of an individual, human security has a psychological nature, established in human consciousness); sociological (security discourse is derived from the sphere of social life, social world of a man, it is emphasized on its social conditionality and structure); historical (security discourse has a historical predicament, its origins are observed in the most ancient period of human history, the emphasis is placed on the civilizational universality of security discourse); theological (adventure for the ways to ensure security has its origins in human religious commitment and inevitably leads him to God as the highest guarantor of security and grace both dar al-fana and in Other Side). It is established that the indicated scientific paradigms intersect in one way or another while studying security discourse and while searching for its origins, compet to a lesser extent than before, enriching each other.

Conclusion, prerequisites for the emergence of security discourse in the history of political and legal thought should be considered as a set of social and epistemological conditions that allowed the emergence (emergence) of initial rational ideas about the relationship between security and danger in human life, their origin, security and subjects capable of it to ensure, for the further development of these ideas in the development of political and legal doctrines (doctrines) of subsequent historical periods. The formation of such a discourse, in terms of social preconditions, should be interpreted as a natural result of the complexity of social life, its separation from the natural and supernatural worlds, attempts to understand security as real and desirable, in terms of public interest, human protection from internal and external threats. Such preconditions can be considered the emergence of human society with its gradual social differentiation and structuring of subjects and objects of security. The epistemological preconditions of security discourse were the transition from subject-specific to abstract thinking, the formation of the first abstract logical "procategories", which generalized human life experience in the field of desirable, appropriate and safe, understanding the problem of security as universal for natural, social and supernatural (otherworldly) worlds. in the structure of mythological thinking.

Key words: security, primitive society, consciousness, security discourse, social preconditions, epistemological preconditions.

Феномен національної безпеки розглядається нині вже не лише в політичному, але й у правовому дискурсі. Адже в історії цивілізації право завжди виконувало й виконує свою найважливішу соціальну функцію - створення та збереження суспільного миру, гарантування безпеки людині й суспільству [1, с. 45-48; 2, с. $118 ; 3$, с. 4; 4, с. 170-174]. А, відповідно, питання безпеки людини, суспільства та держави пронизують майже всі сфери суспільних відносин і об'єктивно мають бути предметом регулювання з боку права [5, с.12]. Так, дослідники історії виникнення права і держави на сьогодні переважно обстоюють спільні позиції щодо того, що в контексті соціального регулювання певна стандартність, передбачуваність, надійність і загальна зрозумілість поведінки оточуючих людей дають кожній людині певну гарантію безпеки ії життя і діяльності [6, с. 197]. Право ж 
своїм функціональним призначенням має, зокрема, вирішення конфліктних ситуацій і приведення суспільних відносин до стану упорядкованості, стабільності й безпеки у найширшому розумінні цього слова. Відповідно, сукупність норм міжнародного й національного права, безумовно, слугує упорядкуванню тих відносин, які стосуються безпекової сфери суспільного існування [7, с. 20].

Зрозуміло, що реалізація безпекової (або охоронно-безпекової) функції правом зумовлює його тісний зв'язок із явищем національної безпеки: право виконує функцію гарантування цієї безпеки, а стан безпеки уможливлює, своєю чергою, належне функціонування права як ключової нормативної системи сучасного суспільства. Щоправда, варто зазначити, що у вітчизняній теоретико-правовій літературі безпекова функція права подекуди свого виокремлення не зазнає [8, с. 185-195].

Зрештою, поза категорією безпеки історію цивілізації неможливо собі уявити: сама цивілізованість багато чому синонімічна безпечності існування і людини, і суспільства як соціального цілого. Це засвідчує глибоку онтологічну, інституційну, функціональну, нормативну та аксіологічну вкоріненість явища національної безпеки в розвиткові цивілізації як такої. I хоча властиво поняття національної безпеки, принаймні в сучасному його тлумаченні, $\epsilon$ відносно недавнім - воно починає широко вживатися в політико-правовому лексиконі з 40-х років XX століття, - все ж його інваріанти в історичному розрізі сягають своїх витоків сивої давнини людської історії. Відповідно, цілком закономірним $\epsilon$ висновок учених про те, що упродовж усієї історії розвитку людства проблема безпеки людини та соціальних утворень (родів, племен, суспільств, держав, людської цивілізації в цілому) посідала чи не найголовніше місце й була необхідною умовою його подальшого розвитку та самого існування, віддзеркалювалася як його життєво важливий інтерес [9, с. 26-27; 10, с. 34].

Проблема формування безпекового дискурсу в історії політико-правової думки тривалий час досліджується різними науками - соціологією, релігієзнавством, без- пекознавством (сек'юрітологією), етнографією, історією, історією держави і права, історією політичних і правових учень. Кожна з цих наук підходить до досліджуваного предмету під «своїм» кутом зору та із власним методологічним арсеналом. Відповідно, можна констатувати, що натепер у науці склалося кілька пануючих парадигм в осмисленні порушеної проблематики, що умовно можна окреслити так: міфологічна (проблема безпеки в давньому світі постала як наслідок міфологізації природних і соціальних небезпек, їх міфолого-символічної інтерпретації у свідомості людини; основні представники цього напряму: А. Кун, Ф. Мюллер, Б. Спіноза, В. Шварц та інші), філософська (поява безпекового дискурсу пояснюється ії̈ виокремленням із загальнофілософського знання, його витоки і розвиток «синхронні» етапам розвитку філософії; основні представники цього напряму: К. Барт, Г. Гегель, Р. Отто, У. Джеймс, Г. Олпорт, Ф. Шлейєрмахер, Л. Штернберг та інші), антропологічна (формування вчення про безпеку людини і суспільства виводиться із природи людини, її світу, потреб та інтересів; основні представники цього напряму: Ж. Марітен, Г. Марсель, Е. Муньє, Ф. Ніцше, П. Тейяр де Шарден, Л. Фейєрбах, Д. Штраус, Д. Юм та інші), психологічна (безпекові питання оформлюються в окремий напрям мислення під впливом психологічної структури особистості, безпека людини має психологічну природу, вкорінена у свідомості людини; основні представники цього напряму: Ж. Жане, В. Вундт, Л. Леві-Брюль, 3. Фройд, К. Юнг та інші), соціологічна (безпековий дискурс виводиться зі сфери соціального буття, соціального світу людини, наголошується на його соціальній обумовленості та структурованості; основні представники цього напряму: М. Вебер, Ж. Гурвіч, Е. Дюркгейм, Р. Ієринг, К. Ллевелін, П. Сорокін, М. Тимашев та інші), історична (безпековий дискурс має історичну обумовленість, її витоки вбачаються в найдавнішому періоді історії людства, наголошується на цивілізаційній універсальності безпекового дискурсу; основні представники цього напряму: Д. Віко, Ж. Кондорсе, А. СенСімон, Г. Спенсер, А. Тойнбі, О. Шпенглер, Дж. Фрезер та інші), теологічна (пошуки 
шляхів забезпечення безпеки мають витоки в релігійності людини й невідворотно приводять її до Бога як найвищого гаранта безпеки й благодаті як у земному, так і в потойбічному світі; основні представники цього напряму: Г. Лейбніц, Й. Фіхте, А. Швейцер, Ф. Шеллінг та інші). Нині означені наукові парадигми так чи інакше перетинаються в дослідженні безпекового дискурсу й пошуках його витоків, меншою мірою конкурують, аніж раніше, взаємозбагачуються.

Як ключова й визначальна домінанта життєдіяльності суспільства, національна безпека, природно, не може залишатися незмінною у різних умовах трансформації особистості, суспільства, держави, а тому осмислення ії сутності та змісту потребує історико-правового підходу [11, с. 26]. Відтак, категорія національної безпеки $\epsilon$ історико-правовою в тому сенсі, що національна безпека, з одного боку, стала неодмінною умовою розвитку держави й права, зазнаючи їх зворотного впливу (нині він стає дедалі інтенсивнішим, помітнішим, різноманітнішим за формами свого прояву), а з іншого боку, це явище міцно вмонтоване в історію особистості, суспільства, держави, цивілізації. Це не означає, що вектор правового розвитку, заданий колись, залишається сталим і незмінним, не означає, що він зумовлює своєрідність і жорстку детермінованість національної безпеки «тут і тепер» тільки історичним минулим, назавжди зафіксованими світоглядними чи культурними домінантами соціуму. Навпаки, він дає змогу констатувати, що цей феномен «живе», змінюється, розвивається у своїй історії, спирається на досвід минулих поколінь (а точніше, розуміння вказаного досвіду), заперечуючи чи продовжуючи його. Як вдало показав французький соціолог М. Фуко, «немає механізмів безпеки, що заміщають дисциплінарні механізми, які своєю чергою заміняли 6 собою механізми правової законності. Посутньо, перед вами низка складних систем, де з переходом від попередньої до наступної трансформуються, удосконалюються, в усякому випадку ускладнюються, звісно, і самі техніки як такі <...>» $>12$, с. 22].

Історичність національної безпеки як складного політико-правового явища може бути осмислена у двох взаємопов'язаних площинах - у ракурсі еволюції відповідного феномену і в розрізі еволюції політико-правової думки щодо нього, тобто у вимірах інституційної та інтелектуальної історії [13, с. 56]. Тим самим така еволюція охоплює одночасно два взаємопов'язані «потоки» - і світ матеріального буття права (права як сущого), і світ правових ідей (права як належного). У матеріальному аспекті така історичність національної безпеки зумовлює особливості існування цього правового явища, а в ідеальному - визначає особливості пізнання й розуміння національної безпеки, зокрема конкретно-історичних форм ії прояву, акцентуванння на важливості тих чи інших аспектів цього явища а також на його цінності для кожного конкретного суспільства або й цивілізації в цілому [14, c. $146-147]$.

Так, у матеріальному (інституціональному) аспекті «право національної безпеки формується історично на тлі соціальних потрясінь, які обумовлюють створення окремими державами надійного захисту власних інтересів у міжнародному просторі з одночасним нормативно-правовим обґрунтуванням усієї сукупності таких дій і використанням можливостей національної та міжнародної правових систем» [15, с. 19]. Натомість в ідеальному (інтелектуальному) вимірі не лише осмислюються матеріальні умови буття права національної безпеки (правове регулювання національної безпеки як таке), але - ширше - зазнають осмислення світоглядні, методологічні, онтологічні, функціональні та аксіологічні підстави цього феномену, його конкретно-історичні імплікації залежно від конкретного періоду часу й своєрідності відповідних суспільних потреб. Крім того, інтелектуальне осмислення цієї проблематики часом впливає на розвиток державно-правових підходів до закріплення питань національної безпеки на рівні нормативно-правових актів і в судовій практиці, а також, зрештою, сприяє кристалізації відповідних правових поглядів на рівні правової доктрини.

Тому, варто погодитися 3 думкою B. Шаблистого, який зазначив, що «вивчення історії філософсько-правових поглядів на проблему безпеки людини, 
суспільства й держави свідчить про те, що вона завжди стимулювала політиків, державних діячів, вчених і практиків до пошуку оптимальної системи забезпечення безпеки, насамперед держави та її правителів. Водночас діапазон точок зору був досить широким: від визнання первинності гарантій існування державного апарату й рівності прав на безпеку суспільства, людини, держави; до необхідності виділення переважного права людини на безпечне існування» $[16$, с. 110$]$.

Варто врахувати і те, що, як відомо, «у періоди повільного поступового розвитку історії обрій майбутнього, доступний для огляду, максимально далекий, і можливість прогнозування досить таки велика. Так, коли ми йдемо по прямій дорозі, ми бачимо далеко поперед себе. Інша справа - час перелому. Обрій майбутнього, доступний для огляду, і можливість його прогнозування тут стискається до мінімуму через множину крутих поворотів. Тому, оскільки майбутнє лякає своєю невідомістю, і впевненість в завтрашньому дні раптом знижується, виникає життєва необхідність постійного звернення до пройденого, прожитого, шукаючи в ньому фундаментальні основи існування» $[17$, с. 103 ; 18 , с. 18, с. 8 ]. 3 такого погляду безпекова проблематика дійсно «губиться» в товщі історичного часу, а ії наступний розвиток позначає віхи історії держави й права, впливає на них, чи не найвиразніше постає як своєрідна онтологія конфліктності, «війни й миру».

Проблема безпечного існування людської цивілізації виникла вже з появою homo sapiens й завжди посідала одне з ключових місць у їі свідомій діяльності. Як відзначив український учений-конституціоналіст В. Антонов, «прагнення до безпеки стає однією із головних та спонукальних причин об'єднання наших пращурів у суспільство. Потреба у безпеці, як і саме поняття «безпека» від «кого чи від чого», виникає одночасно з появою людської істоти. Інтенсивність і масштаби цієї нагальної потреби постійно зростали: безпека виступає найголовнішою метою діяльності та захисту окремих індивідів, а в цивілізаційному поступі стає необхідною умовою існування суспільства та держави» [19, с. 35]. На думку іншого вітчизняного дослідника В. Копанчука, «протягом усієї історії світової цивілізації забезпечення безпеки було головною метою існування суспільства, оскільки вона притаманна всій соціальній структурі суспільства від конкретної особи до будьякого об'єднання людей» [20, с. 7].

Стикаючись із численними природними й соціальними факторами, які несли (чи були здатні принести) шкоду людині, іiі господарству, відтворенню роду, племені тощо, люди, зазвичай, невідворотно мусили мало не щодня реагувати на такі небезпеки й загрози. Простір, який звідусіль щільно оточував людину, був переважно світом невідомого, непізнаного, а тому являв собою зону численних загроз та небезпек, що повсякчас чигали на людину - хижі звірі, холод і повені, виснажлива спека й брак їжі та води, агресивні сусіди й численні хвороби тощо. Диференціація небезпек і широта їх систематики [21, с. 170-173] накладалися на їхню повторюваність, що зумовлювало вплив на практичний досвід людини.

Отже, саме неопанований простір, що звідусіль оточував людину, був суцільним полем мало не щоденних загроз ії̈ життю та здоров'ю, зрештою, й виживанню самого роду homo sapiens. Другий вагомий елемент загроз і небезпек - їхня повторюваність (типізація), що направду відкривала широкий простір для їх осмислення та згодом - раціонального конструювання сфери «безпечного». Адже, як зауважував М. Фуко, «безпека орієнтована на облаштування середовища у зв'язку з подіями, точніше кажучи, серіями подій або можливих елементів - серіями, які потрібно упорядкувати в неоднозначних за своєю природою та мінливих умовах» [22, с. 38-39].

Отже, безпека для найдавніших людей мала три ключових виміри: це вимір простору (простір безпеки), у межах якого мешкала людина та її рід (громада), вимір часу (повторюваність небезпек та загроз) та вимір населення. В останньому вимірі безпеку як таку можна було позначити саме для «своїх» - членів своєї громади, роду, згодом племені, які протистояли іншим, «чужим», які теж уособлювали джерело небезпеки, причому не менш вагоме, ніж природні стихії. Чужинці уособлювали фізичне насильство, були носіями загрози 
етноциду, що корінилися в соціолого-психологічних установках особистості в первісному суспільстві [23, с. 38-39]. Отже, розподіл на своїх і «чужих» здавна провів своєрідний антропологічний водорозділ в уявленнях первісних людей про безпеку як набуток і властивість саме «свого» роду, племені, народу й став своєрідною культурною універсалією [24, с. 6-10]. Звісно, за найдавніших умов мови про національну безпеку не було і не могло бути. Вона на той час поставала як безпека суттєво вужчого та більш визначеного кола осіб - громади, роду, племені тощо. Безпекові питання вищого антропо-соціального порядку були ще далеко попереду.

Передумови виникнення безпекового дискурсу в історії політико-правової думки слід розглядати як сукупність соціальних і гносеологічних умов, що уможливили появу (виникнення) першопочаткових раціональних уявлень про співвідношення безпеки й небезпеки в житті людини, їх походження, засоби забезпечення безпеки та суб'єктів, здатних ії̈ забезпечити, задля подальшого розвитку цих уявлень у розвиткові політико-правових учень (доктрин) наступних історичних періодів.
Процеси політо- й правогенезу стимулювали розвиток безпекового дискурсу як у соціальному, так і в гносеологічному вимірах. Перші уявлення про безпеку були ще додержавними й доправовими. Вони містилися здебільшого в міфологічних та релігійних уявленнях людей, а закріплювалися у свідомості членів пізньопервісного суспільства, транслювалися як елемент життєвого досвіду від поколінь до поколінь, збагачуючись мірою ускладнення організації соціального життя та способів його осмислення. Політизація та юридизація стали ознаками концептуалізації безпекового дискурсу, набуття ним вищої форми «соціальності».

Власне, формування такого дискурсу в розрізі соціальних передумов слід інтерпретувати як закономірний результат ускладнення соціального життя, його відокремлення від природного й надприродного світів, спроб осмислити безпеку як реальний і бажаний із боку загальносоціального інтересу стан захищеності людини від внутрішніх і зовнішніх загроз. Такими передумовами можна вважати виникнення людського суспільства з його поступовою соціальної диференціацією та структуруванням суб'єктів та об'єктів безпеки.

\section{ЛITEPATУРА:}

1. Ісаєва В.В. Функції права : теоретико-правовий аналіз. Часопис Київського університету права. 2013. № 1. С. 45-48.

2. Ковальський В.С. Охоронна функція права : монографія. Київ : Юринком Інтер, 2010. 336 с.

3. Макаренко Л.О. Теоретико-методологічні аспекти пізнання та формування правової культури : дис. ... д-ра юрид. наук : 12.00 .01 ; Інститут держави і права ім. В.М. Корецького НАН України. Київ, 2019. 441 с.

4. Тихомиров Д.О. Теоретичні аспекти правового забезпечення безпеки. Підприємництво, господарство і право. 2019. № 8. С. 170-174.

5. Мурадян Э.Р. Конституционно-правовые основы взаимодействия человека и государства в сфере обеспечения безопасности личности : автореф. дисс. ... канд. юрид. наук : 12.00.02 ; Юж.-Ур. гос. ун-т. Челябинск, 2011. 27 с.

6. Кашанина Т.В. Происхождение государства и права : Учебное пособие. Москва : Высшая школа, 2004. 325 с.

7. Богуцький П.П. Теоретичні основи становлення і розвитку права національної безпеки України : дис. ... д-ра юрид. наук : 12.00 .01 ; Науково-дослідний інститут інформатики і права НАПрН України. Київ, 2020. 445 с.

8. Тимошенко В.І. Вступ до курсу «функції права». Право України. 2017. № 2. С. 185-195.

9. Андреевский И.Е. Полицейское право. Санкт-Петербург : Типография В.В. Пратцъ, 1874. Т. 1.648 с.

10. Антонов В.О. Конституційно-правові засади національної безпеки України : монографія / наук. ред. Ю.С. Шемшученко. Київ : ТАЛКОМ, 2017. 576 с.

11. Чапчиков С.Ю. Концептуальные основания национальной безопасности и механизм ее обеспечения : теоретико-правовое исследование : дисс. ... д-ра юрид. наук : 12.00 .01 ; Юго-Западный гос. ун-т. Курск, 2018. 412 с. 
12. Фуко М. Безопасность, территория, население. Курс лекций, прочитанных в Колледже де Франс в 1977-1978 учебном году / Пер. с фр. В.Ю. Быстрова, Н.В. Суслова, А.В. Шестакова. Санкт-Петербург : Наука, 2011. 554 с.

13. Копча В.В. Методологія дослідження правового явища : поняття, структура, інструментарій. Часопис Київського університету права. 2020. № 1. С. 54-58.

14. Вовк Д.О. Правова традиція, правова культура, правова система : підходи до розуміння співвідношення. Вісник Національної юридичної академії України імені Ярослава Мудрого. 2012. № 3 (13). С. 145-148.

15. Богуцький П.П. Теоретичні основи становлення і розвитку права національної безпеки України : дис. ... д-ра юрид. наук : 12.00.01; Науково-дослідний інститут інформатики і права НАПрН України. Київ, 2020. 445 с.

16. Шаблистий В.В. Історико-правові аспекти філософської концепції безпеки людини. Право і суспільство. 2012. № 5. С. 109-115.

17. Бахтин М.В. Историческое мышление в эпохи катастроф. Социальный кризис и социальная катастрофа : Сборник материалов конференции. Санкт-Петербург : СанктПетербургское философское общество, 2002. С. 103-106.

18. Грищук О.В. Філософія конституційних цінностей : Монографія. Київ : «Компанія BAITE», 2019. 434 C.

19. Антонов В.О. Конституційно-правові засади національної безпеки України : монографія / наук. ред. Ю.С. Шемшученко. Київ : ТАЛКОМ, 2017. 576 с.

20. Копанчук В.О. Становлення та розвиток державної політики у сфері національної безпеки та охорони громадського порядку в сучасних глобалізаційних умовах : монографія. Харків : НУЦЗУ, 2020. 279 с.

21. Леви-Стросс К. Структурная антропология / Пер. с фр. В.В. Иванова. Москва : Изд-во ЭКСМО-Пресс, 2001. 576 с.

22. Фуко М. Безопасность, территория, население. Курс лекций, прочитанных в Колледже де Франс в 1977-1978 учебном году / Пер. с фр. В.Ю. Быстрова, Н.В. Суслова, А.В. Шестакова. Санкт-Петербург : Наука, 2011. 554 с.

23. Назаретян А.П. Антропология насилия и культура самоорганизации. Очерки по эволюционно-исторической психологии. 4-е изд. Москва : Ленанд, 2015. 256 с.

24. Мальцева К.С. Опозиція «своє / чуже» як культурна універсалія. Наукові записки НаУКМА. 2002. Т. 20-21 : Теорія та історія культури. С. 6-10. 